\title{
Effects of Mixed Probiotic Spores of Bacillus Coagulans and Bacillus Subtilis on Gut Microbiota and Intestinal and Liver Damage of Rats Infected with Salmonella Typhimurium
}

Somaye Mazkour

Shiraz University School of Veterinary Medicine

Seyed Shahram Shekarforoush ( $\nabla$ shekar@shirazu.ac.ir)

Shiraz University School of Veterinary Medicine https://orcid.org/0000-0001-6247-8462

Sara Basiri

Shiraz University School of Veterinary Medicine

Fatemeh Namazi

Shiraz University School of Veterinary Medicine

Forough Zarei-Kordshouli

Shiraz University School of Veterinary Medicine

Research article

Keywords: B. subtilis, B. coagulans, Salmonella infection, gut microflora

Posted Date: September 8th, 2020

DOl: https://doi.org/10.21203/rs.3.rs-55588/v1

License: (c) (i) This work is licensed under a Creative Commons Attribution 4.0 International License. Read Full License 


\section{Abstract}

Background: Although the intestinal lumen is a major way for the entrance of pathogens such as Salmonella, they face a dense microbiota in the gut lumen. This community confers health benefits. The probiotics enhance the colonization resistance and direct inhibitory effects against pathogens, which are important in reducing the incidence, duration of gastroenteritis and also histopathological effects.

Methods: In this study spore of two probiotic bacteria, Bacillus subtilis and Bacillus coagulans were fed to rats for three weeks through their daily water intake after which Salmonella Typhimurium was gavaged to the rats. On days 1, 3, 5 and 7 after gavaging, intestinal microbiota and days 1, 3, 5 and 7 after gavaging, gut and liver histopathological changes were evaluated.

Results: In comparison to the control group, Salmonella caused no change in spore and aerobic bacteria population but it caused anaerobic and coliform bacteria increase and LAB reduction. But $B$. subtilis and $B$. coagulans accompaniment with salmonella reduced the anaerobe and coliform bacteria and decreased the LAB population following Salmonella infection. Also, the histopathological evaluation showed that these probiotic attenuated shortening and fusion of villi, mononuclear cells infiltration, submucosal edema and epithelial necrosis in the intestine, hepatocyte degeneration and mononuclear cells infiltration in the liver which occurred due to Salmonella infection.

Conclusion: $B$. subtilis and $B$. coagulans help the maintenance of the gut microflora population and reduce the histopathological effects when exposing to the Salmonella, which, causes the reduction of this pathogen effects and early recovery.

\section{Background}

Salmonella infection remains a distressing public health concern worldwide [1]. Salmonella strains are adapted into various environments, including human, animal and non-animal hosts due to their genetic make-up [2]. Non-Typhoidal Salmonella (NTS) refers to Salmonella strains other than $S$. Typhi and $S$. Paratyphi which are found in animal reservoirs. In humans, NTS infections cause gastroenteritis or 'stomach flu', which is accompanied by symptoms such as non-bloody diarrhea, vomiting, nausea, headache, abdominal cramps, and myalgia and sometimes hepatomegaly and splenomegaly [3]. Among NTS, S. Typhimurium and $S$. Enteritidis are recognized as important foodborne pathogens [4, 5]. Nowadays Salmonella spp. are becoming resistant to antibiotics, which makes the treatment so difficult $[6,7]$.

Although the intestinal lumen is a major way for pathogens entrance such as Salmonella, the pathogens face a dense microbiota in the gut lumen. This community confers health benefits [8], including the prevention of enteropathogen colonization and growth through competition for nutrients [9, 10]. Some microbiota strains secrete inhibitory compounds, preventing the growth of invading pathogens [11]. Other microbiota strains may compete for binding sites on the mucous surface of the epithelium. Also, the resident microbiota causes an oxygen-depleted environment, which reduces the growth of facultative anaerobic pathogens like Salmonella spp. [11, 12].

Probiotics are defined by the Food and Agriculture Organization of the United Nations (FAO)/WHO as "live microorganisms which when administered in adequate amounts confer a health benefit on the host". The mechanism of probiotic action is likely to be multifactorial. The enhancement of colonization resistance and direct inhibitory effects against pathogens are important in reducing the incidence and duration of gastroenteritis. They also slow down the pathogens through the production of inhibitory compounds (such as bacteriocins), reduction of luminal pH through the production of short-chain fatty acid, competition for nutrients and adhesion sites on the intestinal mucosa and submucosa, modulation of the immune response and regulating of gene expression (for instance, the expression of mucin genes) $[13,14]$. The mechanism used by probiotics within the human gut microbiota is unclear [15]. Spore-former probiotics are so important due to their high vitality against gastric acid and bile salts [16]. Spores of Bacillus spp. commercially used as probiotics, and unlike Lactobacillus spp., they are dormant [17]. Consequently, this study was planned to evaluate the preventive effects of spores of Bacillus subtilis and Bacillus coagulans as a probiotic on gut microbiota population and intestinal and liver damage of rats infected with Salmonella Typhimurium.

\section{Methods}

\section{Study settings}

In this experimental study 80 Spargue-Dawley rats weighting 170-180 gr were procured from the Department of animal lab, Shiraz University of Medical Sciences, Iran. They were housed in plastic cages and kept under 12-hour light/ dark condition, a temperature of $20-25^{\circ} \mathrm{C}$, humidity of $50-60 \%$, and free access to food (commercial standard pellets) and water in order to adaptation to the new environment.

After an acclimatization period of 1 week, they were randomly divided into four main groups, each containing five subgroups (four rats in each subgroup) and treated as follows:

1. Blank Control group: Receiving drinking water containing $0.1 \%$ dextrose for 4 weeks and intragastric gavage of $0.5 \mathrm{ml}$ normal saline and $0.5 \mathrm{ml} 6 \%$ ( $\mathrm{W} / \mathrm{v}$ ) $\mathrm{NaHCO}_{3}$ (to neutralize the gastric acid) in day 22 of the study.

2. Probiotic Control group: Receiving drinking water containing $5 \times 10^{7}$ spore/ml B. subtilis and $5 \times 10^{7}$ spore/ml B. coagulans for 4 weeks and intragastric gavage of $0.5 \mathrm{ml}$ normal saline and $0.5 \mathrm{ml} 6 \%(\mathrm{w} / \mathrm{v}) \mathrm{NaHCO}_{3}$ in day 22 of the study.

3. Salmonella: Receiving drinking water containing $0.1 \%$ dextrose for 4 weeks and intragastric gavage of $1 \times 10^{9} \mathrm{CFU} \mathrm{S}$. Typhimurium in $0.5 \mathrm{ml}$ physiological saline and $0.5 \mathrm{ml} 6 \%(\mathrm{w} / \mathrm{v}) \mathrm{NaHCO}_{3}$ in day 22 of the study. 


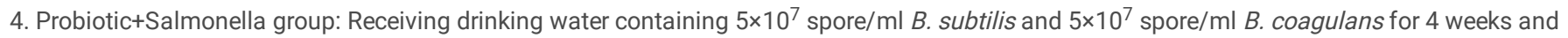
intragastric gavage of $1 \times 10^{9} \mathrm{CFU} S$. Typhimurium in $0.5 \mathrm{ml}$ normal saline $+0.5 \mathrm{ml} 6 \%(\mathrm{w} / \mathrm{v}) \mathrm{NaHCO}_{3}$ in day 22 of the study.

The concentration of probiotic spores fed to the rats was determined based on our previous study [18] and the concentration of challenged bacterium was determined based on Havelaar et al. (2001), Abdel Hamid et al (2013) and Kim et al (2013) [19 - 21].

The trial was permitted by the commission on animal ethics, Shiraz University, Shiraz, Iran (IACUC no: 4687/63). Moreover, the guidance of the European Council Directive $(86 / 609 / E C)$ of November 24,1986 , about the animal protection, was entirely deliberated for test trials. Effects of mixed probiotic spores of Bacillus coagulans and Bacillus subtilis on gut microbiota and intestinal and liver damage of rats infected with Salmonella Typhimurium were evaluated.

\section{Preparation of probiotic bacteria}

Spray-dried spore of B. coagulans (PRM101) and B. subtilis (PRM102) in dextrose powder $\left(1 \times 10^{11}\right.$ spore per gram) was donated separately by the Pardis Roshd Mehregan Company, Iran. To confirm the spore concentrations of the probiotics, one gram of each powder was dissolved in $100 \mathrm{ml}$ tap water $\left(1 \times 10^{9}\right.$ each spore $/ \mathrm{ml}$ ) and heated at $80^{\circ} \mathrm{C}$ for $15 \mathrm{~min}$, to kill the vegetative cells, and surface plating on Brilliant Green agar (BG agar, Merck, Germany) after tenfold serial dilution was done.

\section{Preparation of Salmonella}

In order to prepare the solution for intragastric gavage, a pure colony of Salmonella enterica serovar Typhimurium (S. Typhimurium) (ATCC 14028) was cultured in $100 \mathrm{ml}$ of Tryptic Soy Broth (TSB) (Merck, Germany) for $24 \mathrm{~h}$ at $37^{\circ} \mathrm{C}$. After incubation, it was centrifuged at $5000 \times \mathrm{g}$ for $10 \mathrm{~min}$ at $4{ }^{\circ} \mathrm{C}$ and then the pellet was re-suspended in $50 \mathrm{ml}$ physiological saline. Plating was performed for the suspension to confirm the concentration of $2 \times 10^{9} \mathrm{CFU} / \mathrm{ml}[22]$.

\section{Salmonella-free confirmation}

For confirmation that the rats are Salmonella-free, on days $0,7,14$ and 21 of the study, fecal samples from each subgroup were taken and examined. One gram of pooled fecal sample from each subgroup was added into $9 \mathrm{ml}$ lactose broth (Merck, Germany) and incubated at $37^{\circ} \mathrm{C}$ for $24 \mathrm{~h}$. After incubation, $1 \mathrm{ml}$ of that was added to $10 \mathrm{ml}$ Selenite Cystine broth (Merck, Germany) and in parallel, $0.1 \mathrm{ml}$ was added to $10 \mathrm{ml}$ Rappaport Vassiliadis broth (Merck, Germany). They were incubated at $37^{\circ} \mathrm{C}$ and $42^{\circ} \mathrm{C}$, respectively, for $24 \mathrm{~h}$. After which a loop of the selective enrichment broth was cultured on Xylose Lysine Deoxycholate agar (XLD agar, Merck, Germany) and Brilliant Green agar (BG agar, Merck, Germany). The plates were incubated at $37{ }^{\circ} \mathrm{C}$ for $24 \mathrm{~h}$ and checked for Salmonella colonies [21].

\section{Intestinal microflora enumeration}

One day before and days 1, 3, 5 and 7 after intragastric gavage of $S$. Typhimurium, a pooled fecal sample from the rats in each subgroup was taken. Just after collection, each sample was weighed, homogenized in sterile phosphate buffer saline (PBS) (pH: 7.2), and tenfold serial dilutions were made in PBS. Aerobic and anaerobic microorganisms were cultured in Plate Count agar (Merck, Germany). LAB were cultured in MRS (de Man, Rogosa, Sharpe) agar (Merck, Germany) and the Coliforms were cultured in VRBL (Violet Red Bile Lactose) agar (Merck, Germany). Anaerobes and LAB medium plates were placed in an anaerobic jar. All plates were incubated at $37^{\circ} \mathrm{C}$ for $48 \mathrm{~h}$. The microflora enumeration was expressed as $\mathrm{CFU} / \mathrm{gr}$. In order to count bacterial spores in fecal samples, the homogenized samples in PBS were put into a water bath at $80^{\circ} \mathrm{C}$ for $10 \mathrm{~min}$ and cooled immediately. Then the samples were serially diluted in PBS and cultured in Plate Count agar (Merck, Germany). The plates were incubated at $37^{\circ} \mathrm{C}$ for $48 \mathrm{~h}$. The spore enumeration was expressed as spores/gr. All the samples were cultured in duplicate [23 - 25].

\section{Histopathological evaluation}

On days 3, 5 and 7 after intragastric gavage of $S$. Typhimurium, one rat was chosen randomly from each subgroup (replicated independently five times from each treatment group) and euthanized (by $\mathrm{CO}_{2}$ from commercially available gas cylinders, according to European Communities instructions 1997 ). The euthanized rats were dissected and their liver and intestine (ileum and cecum) were removed. All samples were fixed in $10 \%$ neutral buffered formalin, embedded in paraffin wax, sectioned at $5 \mu \mathrm{m}$, stained with hematoxylin and eosin and examined for histopathological changes by an ordinary light microscope (Olympus, Tokyo, Japan). Histopathological indexes included shortening and fusion of villi, mononuclear cell infiltration, necrosis and submucosal edema in the intestine, and hepatocyte degeneration and necrosis with mononuclear cell infiltration. We used a semi-quantitative scoring method based on the ordinal method [26]. Four grades were considered in scoring as follows: no pathological changes (0), mild, moderate and severe pathological changes scored 1,2 , and 3 , respectively.

\section{Statistical analysis}

The results were analyzed using a one-way analysis of variance and the statistical significance of differences between mean values was analyzed by Duncan's multiple range tests. The Histopathological evaluation were compared by Kruskal- wallis nonparametric test. P-values less than 0.05 (P < 0.05$)$ were considered statistically significant. The analysis was performed using the Statistical Package for Social Sciences (SPSS) software (SPSS 16 for windows, SPSS Inc, Chicago, IL, USA).

\section{Results}


The spore former probiotics (B. coagulans and B. subtilis) significantly increased the number of fecal total aerobics, LAB and spores and reduced the number of coliforms $(P<0.05)$. By gavaging $S$. Typhimurium, no change was observed in the total aerobic and spore count of feces, while it increased the number of coliforms and anaerobics $(P<0.05)$ and decrease the lactic acid bacteria population $(P<0.05)$ in the feces. These observed changes in Salmonella group were different in comparison to the Blank Control group untill $7^{\text {th }}$ day after gavaging $S$. Typhimurium $(P<0.05)$. Using probiotics before gavaging, reduced the number of coliforms and anaerobic bacteria and increased the number of total aerobics, $L A B$ and spores count in comparison to the Salmonella group ( $P<$ 0.05) (Figs. 1-5).

\section{Histopathological evaluation}

The mean \pm SD of histopathological parameters are represented in Tables 1 and 2 . No lesion was observed in the Blank Control (Figs. 6A and 7A) and Probiotic Control groups.

On the $3^{\text {rd }}$ day after gavaging, the histopathological lesions in Salmonella group were mild to moderate shortening and fusion of intestinal villi with mild to moderate mononuclear cells infiltration as well as mild hepatocyte degeneration with mild to moderate mononuclear cells infiltration. While the mild fusion of intestinal villi was observed in the Probiotic+Salmonella group.

In the $5^{\text {th }}$ day after gavaging, the histopathological lesions in Salmonella group were mild to moderate shortening and fusion of intestinal villi with moderate to severe mononuclear cells infiltration, mild to moderate submucosal edema, and mild hepatocyte degeneration with mild to moderate mononuclear cells infiltration. Besides, moderate epithelial necrosis of the intestine was observed in a rat. Concurrent use of probiotic and salmonella significantly reduced these complications and a mild fusion of intestinal villi and mild mononuclear cells infiltration in the liver were observed $(P<0.05)$.

In the $7^{\text {th }}$ day after gavaging, the histopathological lesions in Salmonella group were moderate to severe shortening and fusion of intestinal villi, mononuclear cells infiltration and submucosal edema (Fig. 6B), and moderate hepatocyte degeneration and necrosis (Fig. 7B) with moderate to severe mononuclear cells infiltration (Fig. 7C). Also, there was severe necrosis of intestine in a rat (Fig. 6C). Probiotic+Salmonella group showed mild fusion of the intestinal villi (Fig. 6D) and mild mononuclear cells infiltration in the liver (Fig. 7D).

\section{Discussion}

Colonization is the first step of any infection. But enteropathogenic bacteria face a dense microbial community called microbiota. The microbiota provides an efficient barrier against infections that must be overcome by enteropathogenic bacteria. In this study, we concluded that gavaging $S$. Typhimurium, didn't change the total aerobic and spore count, but it reduced the population of LAB and increased the coliform and anaerobe count. The use of probiotics for three weeks before the rats became infected with Salmonella, changed the gut microflora population so that the population of beneficial $L A B$ increased and harmful ones such as coliform decreased. Therefore, they prepared the intestinal lumen to fight the pathogen and decreased its colonization. LAB send signals to activate immune cells and induce good mucosal immunostimulation without inducing side effects such as bacterial translocation or a strong inflammatory immune response [27]. As mentioned before, the intestinal microbiota limits the pathogens such as Salmonella infection, one of the mechanisms referred to as colonization resistance [28]. Salmonella (as a gastrointestinal pathogen) must overcome the host defenses in order to colonizing and resulting in disease [29], but the usage of B. coagulans and B. subtilis spore before Salmonella entrance created a strong barrier that limited Salmonella mucosal penetration. Also, Thirabunyanon and Thongwittaya (2012) showed that usage of B. subtilis significantly reduced $S$. Enteritidis invasion of intestinal epithelial cells. They expressed that high tolerance of the $B$. subtilis to low $\mathrm{pH}$ and bile salt conditions helps them work well [30].

Cecum and small intestine are two parts of the GI tract that showed inflammatory changes in infection with Salmonella [31, 32]. In our study, histopathological lesions in Salmonella group increased in the $3^{\text {rd }}, 5^{\text {th }}$ and $7^{\text {th }}$ days after gavaging Salmonella. Salmonella caused shortening and fusion of intestinal villi, mononuclear cells infiltration, epithelial necrosis, and submucosal edema. While probiotic bacteria, $B$. coagulans and $B$. subtilis, reduced the hepatic and intestinal lesions induced by $S$. Typhimurium. Invasive $S$. Typhimurium form a gap in the follicle associated epithelium by $M$ cell destruction, resulting in organisms invasion of enterocytes adjacent to the dead cell. Furthermore, replicating Salmonella enters both the apical and basolateral surfaces of enterocytes adjacent to infected M cells [33]. Probiotics reduce this process by a decrease of Salmonella adhesion and colonization. Histopathological effect of S. Typhimurium decreased in intestine and liver, using Lactobacillus acidophilus [34]. Gancarcikova et al (2018) observed that prominent inflammatory changes and the destruction of hepatocytes with $S$. Typhimurium result in infection [35]. The marked alleviation of overall inflammation and hepatocyte necrosis represented treat with Lactobacillus reuteri (LAB). They recorded a significantly reduced mean area of nodules in the livers in LAB group in comparison with an infected control group, probably resulting from a decrease of bacterial load. In the other study, severe mucosal damages occurred by loss of villi, permeation of red blood and inflammatory cells in the mucosa and submucosa in the induced group by pathogenic bacteria Salmonella. Mice receiving Lact. acidophilus, Lact. bulgaricus and Lact. casei had the typical structure of the small intestine tissue with lesser infiltration of inflammatory cells in special areas [36]. Manuel et al, (2017) showed probiotic supplementation (Lact. casei and Lact. paracasei), in the chronic stress model, improved the length and cellularity of the intestinal villi, increased phagocytic activity of peritoneal and spleen macrophages and the humoral response, and protected against Salmonella infection [37].

\section{Conclusion}

Using B. coagulans and B. subtilis before exposure to Salmonella Typhimurium helps the maintenance of the gut microflora population. They inhibit the coliform and anaerobic bacteria count increase and lactic acid bacteria decrease which happens following Salmonella Typhimurium infection. Also, they cause a reduction in Salmonella histopathological effects in the liver and intestine. It can be concluded that using these probiotics leads to a reduction of pathogen effects and early recovery. 


\section{Abbreviations}

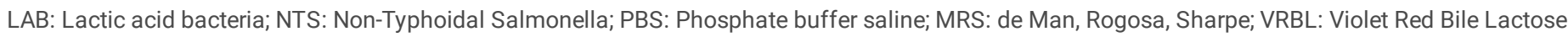

\section{Declarations}

\section{Acknowledgments}

The authors would like to thank the staff of the Department of Food Hygiene and Public Health and Pathology, School of Veterinary Medicine, Shiraz University. The authors also thank Dr. Javad Sajedianfard, Department of Basic Sciences, School of Veterinary Medicine, Shiraz University for supporting this study, Pardis Roshd Mehregan Company, Iran for donating the probiotic bacteria.

\section{Funding}

This work was supported by funds from Shiraz University, Shiraz, Iran (1395/9234308). The funder had no role in study design, data collection and analysis, decision to publish or preparation of manuscript.

\section{Availability of data and materials}

The datasets used and/or analyzed during this study are available from the corresponding author on reasonable request.

\section{Authors' contributions}

SSS, SB and FN conceived and designed the study and critically revised the manuscript. SM and FZK contributed to sample collection and performed laboratory tests. SM analyzed the data and drafted the manuscript. All the authors have reviewed and approved the final manuscript.

\section{Ethics approval and consent to participate}

All methods were performed following the relevant guidelines and regulations by Ethical Committees of Shiraz University and approved by the governing body $(1395 / 9234308)$.

\section{Consent for publication}

Not applicable.

\section{Competing interests}

The authors declare that they have no competing interests.

\section{References}

1. Hurley D, McCusker MP, Fanning S, Martins M. Salmonella-host interaction - modulation of the host innate immune system. Front Immunol. $2014 ; 5: 481$.

2. Eng SK, Pusparajah P, Ab Mutalib NS, Ser HL, Chan KG, Lee LH. Salmonella: A review on pathogenesis, epidemiology and antibiotic resistance. Front Life Sci. 2015;8(3):284-93.

3. Acheson D, Hohmann EL. Nontyphoidal salmonellosis. Clin Infect Dis. 2001;32(2):263-9.

4. Gray JT, Fedorka-Cray PJ. Salmonella. In Cliver DO, Riemann HP. (Eds.). Foodborne diseases, 2002. p. 55-68. San Diego: Academic Press

5. Yousef AE, Carlstrom C. Salmonella. In Yousef AE, Carstrom C. (Eds.). Food microbiology: A laboratory manual, 2003. p. 167-205. New Jersey: John Wiley \& Sons, Inc.

6. Angulo FJ, Johnson KR, Tauxe RV, Cohen ML. Origins and consequences of antimicrobial-resistant nontyphoidal Salmonella: implications for the use of fluoroquinolones in food animals. Microb DrugResist. 2000;6(1):77-83.

7. Boyle EC, Bishop JL, GrassI GA, Finlay BB. Salmonella: From pathogenesis to therapeutics. J Bacteriol. 2007;189(5):1489-95.

8. Sommer F, Backhed F. The gut microbiota-masters of host development and physiology. Nat Rev Microbiol. 2013;11(4):227-38.

9. Sonnenburg JL, Xu J, Leip DD, Chen CH, Westover BP, Weatherford J, et al. Glycan foraging in vivo by an intestine-adapted bacterial symbiont. Sci. 2005;307(5717):1955-9.

10. Stecher B. The roles of inflammation, nutrient availability and the commensal microbiota in enteric pathogen infection. Microbiol Spectr. 2015;3:1-17.

11. Stecher B, Berry D, Loy A. Colonization resistance and microbial ecophysiology: using gnotobiotic mouse models and single-cell technology to explore the intestinal jungle. FEMS Microbiol Rev. 2013;37(5):793-829.

12. Freter R, Brickner H, Botney M, Cleven D, Aranki A. Mechanisms that control bacterial populations in continuous-flow culture models of mouse large intestinal flora. Infect Immun. 1983;39(2):676-85.

13. Mack DR, Michail S, Wei S, McDougall L, Hollingsworth MA. Probiotics inhibit enteropathogenic E. coli adherence in vitro by inducing intestinal mucin gene expression. Am J Physiol. 1999;276(4):941-50.

14. Steer T, Carpenter H, Tuohy K, Gibson GR. Perspectives on the role of the human gut microbiota and its modulation by pro- and prebiotics. Nutr Res Rev. 2000;13(2):229-54 
15. Tuohy KM, Probert HM, Smejkal CW, Gibson GR. Using probiotics and prebiotics to improve gut health. Drug Discov Today. 2003;8(15):692-700.

16. Farmer S. Inhibition of pathogens by probiotic bacteria. United State Patent. 2005;6:849,256 B1.

17. Casula G, Cutting SM. Bacillus probiotics: Spore germination in the gastrointestinal tract. Appl Environ Microbiol. 2002;68(5):2344-52.

18. Mazkour, S., Shekarforoush S. S. \& Basiri, S. The effects of supplementation of Bacillus subtilis and Bacillus coagulans spores on the intestinal microflora and growth performance in rat. IRAN. J. Microbiol. 2019;11(3):260-6.

19. Havelaar AH, Garssen J, Takumi K, Koedam MA, Dufrenne JB, Van Leusden FM, de la Fonteyne L, Bousema JT, Vos JG. A rat model for dose-response relationships of Salmonella Enteritidis infection. J appl microbial. 2001;91(3):442-52.

20. Abdel Hamid MFM, El-Gohary FA, Risha E. Incorporation efficacy comparison of probiotic and antibiotic on growth performance, some immunological and biochemical parameters in Salmonella entertidis challenged chicks. Life Sci. 2013;10(4): 3550-8.

21. Kim MS, Yoon YS, Seo JG, Lee HG, Chung MJ, Yum DY. A study on the prevention of Salmonella infection by using the aggregation characteristics of Lactic Acid Bacteria. Toxicol Res. 2013;29(2):129-135.

22. Elmer, G., Surawicz, C. \& McFarland, L. Biotherapeutic agents. A neglected modality for the treatment and prevention of selected intestinal and vaginal infections. JAMA. 1996;275(11):870-6.

23. Haldar L, Gandhi DN. Effect of oral administration of Bacillus coagulans B37 and Bacillus pumilus B9 strains on fecal coliforms, Lactobacillus and Bacillus spp. in rat animal model. Vet World. 2016;9(7):766-72.

24. Shivaramaiah S, Pumford NR, Morgan MJ, Wolfenden RE, Wolfenden AD, Torres-Rodríguez A, Hargis BM, Téllez G. Evaluation of Bacillus species as potential candidates for direct fed microbials in commercial poultry. Poult. Sci. 2011;90(7):1574-

25. Lin SY, Hung ATY, Lu JJ. Effect of supplement with different level of Bacillus coagulans as probiotics on growth performance and intestinal microflora population of broiler chickens. JAnim Vet Adv. 2011;10(1):111-4.

26. Gibson-Corley KN, Olivier AK, Meyerholz DK. Principles for valid histopathologic scoring in research. Vet Pathol. 2013;50(6):1007-15.

27. Perdigon G, Fuller R, Raya R. Lactic acid bacteria and their effect on the immune CIMB. 2001;2(1):27-42.

28. Wijburg OL, Uren TK, Simpfendorfer K, Johansen FE, Brandtzaeg P, Strugnell RA. Innate secretory antibodies protect against natural Salmonella typhimurium infection. JExp Med. 2006;203(1):21-26.

29. Ahmer BMM, Gunn JS. Interaction of Salmonella spp. with the intestinal microbiota. Front Microbiol. 2011;2:101.

30. Thirabunyanon M, Thongwittaya N. Protection activity of a novel probiotic strain of Bacillus subtilis against Salmonella Enteritidis infection. Res Vet Sci. 2012;93(1):74-81.

31. Barthel M, Hapfelmeier S, Quintanilla-Martínez L, Kremer M,Rohde M, Hogardt M, et al. Pretreatment of mice with streptomycin provides a Salmonella enterica serovar Typhimurium colitis model that allows analysis of both pathogen and host. Infect Immun. 2003;71(5):2839-

32. Steinberg RS, Silva LCS, Souza TC, Lima MT, de Oliveira NLG,Vieira LQ, et al. Safety and protective effectiveness of two strains ofLactobacillus with probiotic features in an experimental model ofsalmonellosis. Int J Environ Res Public Health. 2014;11(9):8755-

33. Jones BD, Ghori N, Falkow S. Salmonella Typhimurium initiates murine infection by penetrating and destroying the specialized epithelial M cells of the Peyer's patches. J Exp Med. 1994;180(1):15-23.

34. Gheith IM, Ozbak HA, Hemeg HA, El-Mahmoudy AM. Modulation of acute phase parameters of inflammation by probiotics in albino rats. Eur J Inflamm. 2015;13(2):91-100.

35. Gancarcikova S, Nemcova R, Popper M, Hrckova G, Scirankova1 L, Madar M Mudronova D, SZitnan R. The influence of feed-supplementation with probiotic strain Lactobacillus reuteri ccm 8617 and alginite on intestinal microenvironment of SPF mice infected with Salmonella typhimurium CCM 7205. Probiotics Antimicro. 2018;11(2):493-508.

36. Castillo NA, de Moreno de LeBlanc A, Galdeano CM, Perdigon G. Comparative study of the protective capacity against Salmonella infection between probiotic and nonprobiotic lactobacilli. Appl Microbiol. 2013;114(3):861-76.

37. Manuel PM, Elena B, Carolina MG, Gabriela P. Oral probiotics supplementation can stimulate the immune system in a stress process. JNIM. $2017 ; 8: 29-40$.

\section{Tables}

TABLE 1

Intestine histopathological scores among different groups on 3, 5 and 7 days after gavaging Salmonella

\begin{tabular}{|c|c|c|c|c|c|c|c|c|c|c|c|}
\hline \multirow[b]{2}{*}{ Groups } & \multicolumn{3}{|c|}{ Shortening of villi } & \multicolumn{3}{|c|}{ Fusion of villi } & \multicolumn{3}{|c|}{ Mononuclear cells infiltration } & \multicolumn{2}{|l|}{ Necrosis } \\
\hline & Day 3 & Day 5 & Day 7 & Day 3 & Day 5 & Day 7 & Day 3 & Day 5 & Day 7 & Day 3 & Day 5 \\
\hline Blank Control & $0.0 \pm 0.0^{a}$ & $0.0 \pm 0.0^{a}$ & $0.0 \pm 0.0^{a}$ & $0.0 \pm 0.0^{a}$ & $0.0 \pm 0.0^{a}$ & $0.0 \pm 0.0^{a}$ & $0.0 \pm 0.0^{a}$ & $0.0 \pm 0.0^{a}$ & $0.0 \pm 0.0^{a}$ & $0.0 \pm 0.0^{\mathrm{a}}$ & $0.0 \pm 0.0^{\mathrm{a}}$ \\
\hline Probiotic Control & $0.0 \pm 0.0^{a}$ & $0.0 \pm 0.0^{a}$ & $0.0 \pm 0.0^{a}$ & $0.0 \pm 0.0^{a}$ & $0.0 \pm 0.0^{a}$ & $0.0 \pm 0.0^{a}$ & $0.0 \pm 0.0^{a}$ & $0.0 \pm 0.0^{a}$ & $0.0 \pm 0.0^{a}$ & $0.0 \pm 0.0^{a}$ & $0.0 \pm 0.0^{a}$ \\
\hline Salmonella & $1.3 \pm 0.6^{b}$ & $1.2 \pm 0.8^{b}$ & $2.0 \pm 0.0^{b}$ & $1.3 \pm 0.6^{b}$ & $1.6 \pm 0.6^{b}$ & $2.2 \pm 0.5^{b}$ & $1.7 \pm 0.6^{b}$ & $2.4 \pm 0.6^{b}$ & $2.4 \pm 0.6^{b}$ & $0.0 \pm 0.0^{a}$ & $0.4 \pm 0.9^{a}$ \\
\hline Probiotic+Salmonella & $0.0 \pm 0.0^{\mathrm{a}}$ & $0.3 \pm 0.5^{a}$ & $0.2 \pm 0.5^{\mathrm{a}}$ & $0.7 \pm 0.6^{c}$ & $0.5 \pm 0.6^{a}$ & $0.2 \pm 0.5^{a}$ & $0.0 \pm 0.0^{a}$ & $0.3 \pm 0.5^{a}$ & $0.6 \pm 0.6^{c}$ & $0.0 \pm 0.0^{\mathrm{a}}$ & $0.0 \pm 0.0^{\mathrm{a}}$ \\
\hline
\end{tabular}

Values are mean \pm standard deviation of 5 independent replicates. Score rating: $0=$ no pathological changes; $1=$ mild; $2=$ moderate and $3=$ severe pathological changes, respectively. The different letters indicate significant differences in columns $(P<0.05)$. Blank Control group: Receiving water; Probiotic Control group: 
Receiving water containing $5 \times 10^{7}$ spores $/ \mathrm{ml}$ of $B$. subtilis and $5 \times 10^{7}$ spores $/ \mathrm{ml}$ of $B$. coagulans, Salmonella group: Receiving water and intragastric gavage of $1 \times 10^{9} \mathrm{CFU}$ of $S$. Typhimurium on day 22; Probiotic+Salmonella group: Receiving water containing $5 \times 10^{7}$ spores $/ \mathrm{ml}$ of $B$. subtilis and $5 \times 10^{7}$ spores $/ \mathrm{ml}$ of $B$. coagulans and intragastric gavage of $1 \times 10^{9} \mathrm{CFU}$ of $S$. Typhimurium on day 22.

TABLE 2

Liver histopathological scores among different groups on 3, 5 and 7 days after gavaging Salmonella

\begin{tabular}{|lllllll|}
\hline Groups & \multicolumn{4}{l}{ Hepatocyte degeneration and necrosis } & \multicolumn{4}{l|}{ Hepatocyte degeneration and necrosis } \\
\cline { 2 - 7 } & Day 3 & Day 5 & Day 7 & Day 3 & Day 5 & Day 7 \\
\hline Blank Control & $0.0 \pm 0.0^{\mathrm{a}}$ & $0.0 \pm 0.0^{\mathrm{a}}$ & $0.0 \pm 0.0^{\mathrm{a}}$ & $0.0 \pm 0.0^{\mathrm{a}}$ & $0.0 \pm 0.0^{\mathrm{a}}$ & $0.0 \pm 0.0^{\mathrm{a}}$ \\
\hline Probiotic Control & $0.0 \pm 0.0^{\mathrm{a}}$ & $0.0 \pm 0.0^{\mathrm{a}}$ & $0.0 \pm 0.0^{\mathrm{a}}$ & $0.0 \pm 0.0^{\mathrm{a}}$ & $0.0 \pm 0.0^{\mathrm{a}}$ & $0.0 \pm 0.0^{\mathrm{a}}$ \\
\hline Salmonella & $1.50 \pm 0.58^{\mathrm{b}}$ & $1.60 \pm 0.55^{\mathrm{b}}$ & $2.00 \pm 0.71^{\mathrm{b}}$ & $0.50 \pm 0.58^{\mathrm{b}}$ & $0.40 \pm 0.55^{\mathrm{a}}$ & $1.40 \pm 0.89^{\mathrm{b}}$ \\
\hline Probiotic+Salmonella & $0.20 \pm 0.45^{\mathrm{a}}$ & $0.60 \pm 0.55^{\mathrm{c}}$ & $0.40 \pm 0.55^{\mathrm{a}}$ & $0.00 \pm 0.00^{\mathrm{a}}$ & $0.20 \pm 0.45^{\mathrm{a}}$ & $0.00 \pm 0.00^{\mathrm{a}}$ \\
\hline
\end{tabular}

Values are mean \pm standard deviation of 5 independent replicates. Score rating: $0=$ no pathological changes; $1=$ mild; $2=$ moderate and $3=$ severe pathological changes, respectively. The different letters indicate significant differences in columns $(P<0.05)$. Blank Control group: Receiving water; Probiotic Control group: Receiving water containing $5 \times 10^{7}$ spores/ml of $B$. subtilis and $5 \times 10^{7}$ spores $/ \mathrm{ml}$ of $B$. coagulans, Salmonella group: Receiving water and intragastric gavage of $1 \times 10^{9} \mathrm{CFU}$ of $S$. Typhimurium on day 22 ; Probiotic+Salmonella group: Receiving water containing $5 \times 10^{7} \mathrm{spores} / \mathrm{ml}$ of $B$. subtilis and $5 \times 10^{7}$ spores $/ \mathrm{ml}$ of $B$. coagulans and intragastric gavage of $1 \times 10^{9} \mathrm{CFU}$ of $S$. Typhimurium on day 22.

\section{Figures}

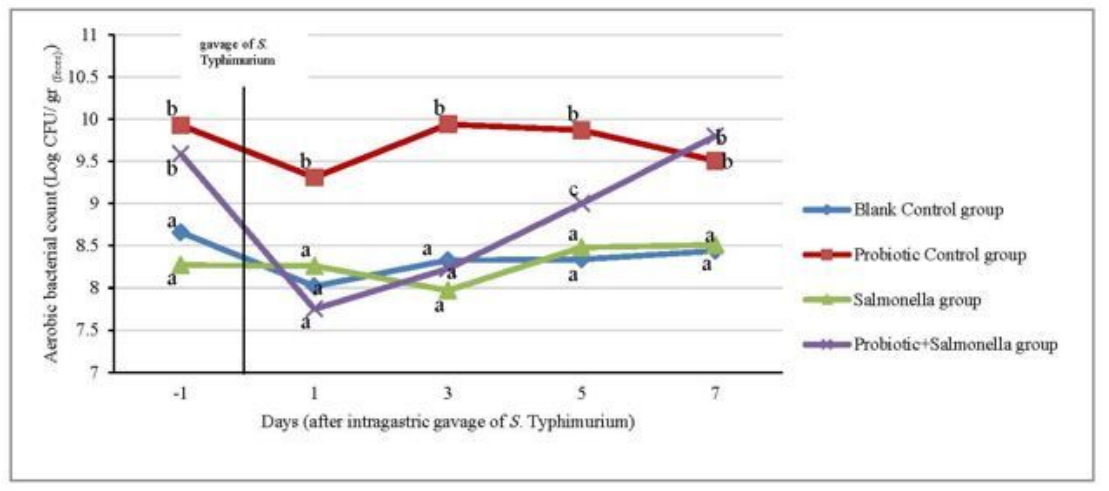

\section{Figure 1}

The logarithm of aerobic bacterial count in feces samples of rats with different treatments before and after intragastric gavage of S. Typhimurium. Values are mean of 5 independent replicates. Blank Control group: Receiving water; Probiotic Control group: Receiving water containing $5 \times 107$ spore/ml B. coagulans and $5 \times 107$ spore/ml B. subtilis ; Salmonella group: Receiving water and intragastric gavage of 1×109 CFU S. Typhimurium; Probiotic+Salmonella group: Receiving water containing 5×107 spore/ml B. coagulans and 5×107 spore/ml B. subtilis and intragastric gavage of 1×109 CFU S. Typhimurium. Different letters indicate significant differences between groups in each day $(P<0.05)$.

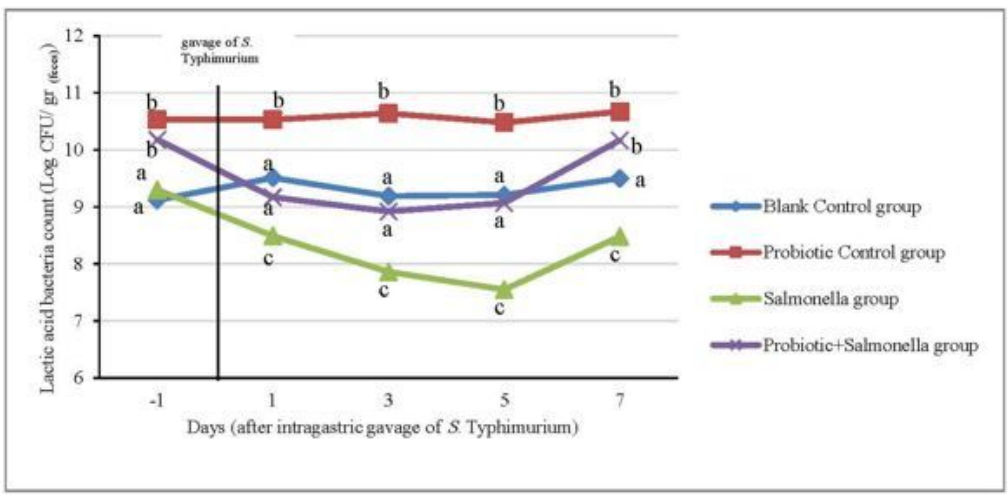

Page $7 / 10$ 
Figure 2

The logarithm of LAB count in feces samples of rats with different treatments before and after intragastric gavage of $\mathrm{S}$. Typhimurium. Values are mean of 5 independent replicates. Blank Control group: Receiving water; Probiotic Control group: Receiving water containing 5×107 spore/ml B. coagulans and $5 \times 107$ spore/ml B. subtilis ; Salmonella group: Receiving water and intragastric gavage of $1 \times 109$ CFU S. Typhimurium; Probiotic+Salmonella group: Receiving water containing $5 \times 107$ spore/ml B. coagulans and $5 \times 107$ spore/ml B. subtilis and intragastric gavage of $1 \times 109$ CFU S. Typhimurium. Different letters indicate significant differences between groups in each day $(P<0.05)$.

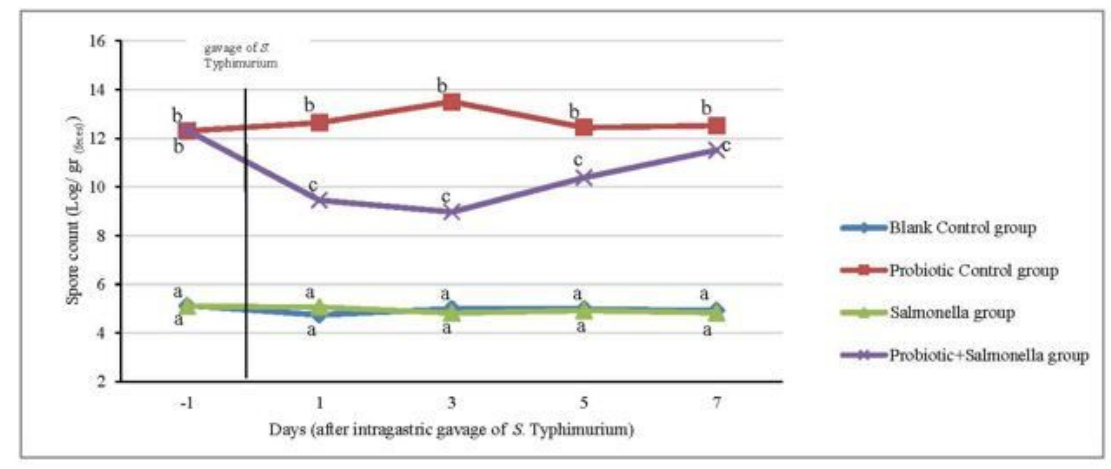

Figure 3

The logarithm of spore count in feces samples of rats with different treatments before and after intragastric gavage of S. Typhimurium. Values are mean of 5 independent replicates. Blank Control group: Receiving water; Probiotic Control group: Receiving water containing 5×107 spore/ml B. coagulans and 5×107 spore/ml B. subtilis ; Salmonella group: Receiving water and intragastric gavage of $1 \times 109$ CFU S. Typhimurium; Probiotic+Salmonella group: Receiving water containing $5 \times 107$ spore/ml B. coagulans and 5×107 spore/ml B. subtilis and intragastric gavage of $1 \times 109$ CFU S. Typhimurium. Different letters indicate significant differences between groups in each day $(P<0.05)$.

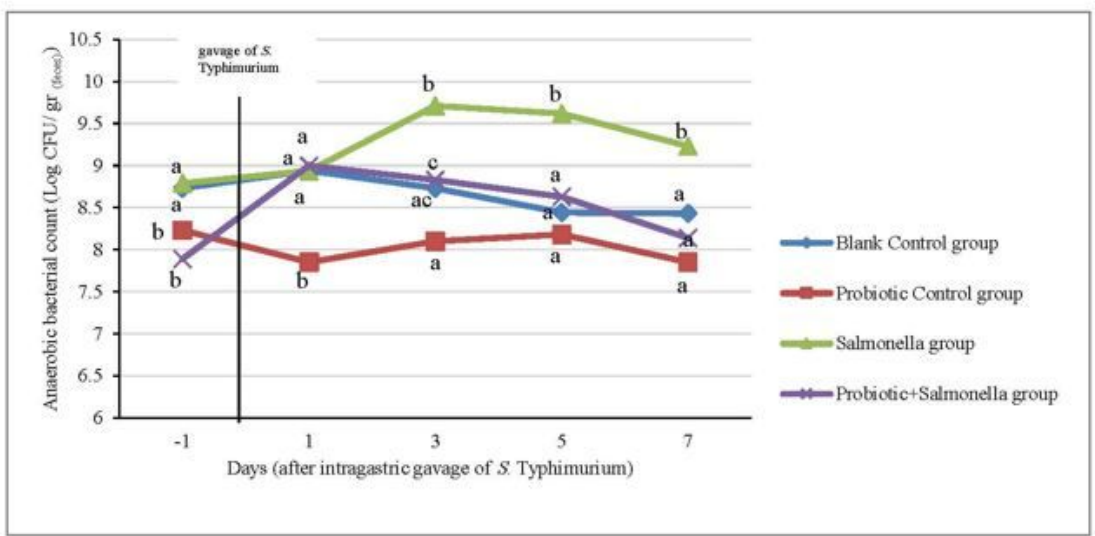

\section{Figure 4}

The logarithm of anaerobic bacteria count in feces samples of rats with different treatments before and after intragastric gavage of S. Typhimurium. Values are mean of 5 independent replicates. Blank Control group: Receiving water; Probiotic Control group: Receiving water containing $5 \times 107$ spore/ml B. coagulans and $5 \times 107$ spore/ml B. subtilis ; Salmonella group: Receiving water and intragastric gavage of $1 \times 109$ CFU S. Typhimurium; Probiotic+Salmonella group: Receiving water containing $5 \times 107$ spore/ml B. coagulans and $5 \times 107$ spore/ml B. subtilis and intragastric gavage of $1 \times 109$ CFU S. Typhimurium. Different letters indicate significant differences between groups in each day $(P<0.05)$. 


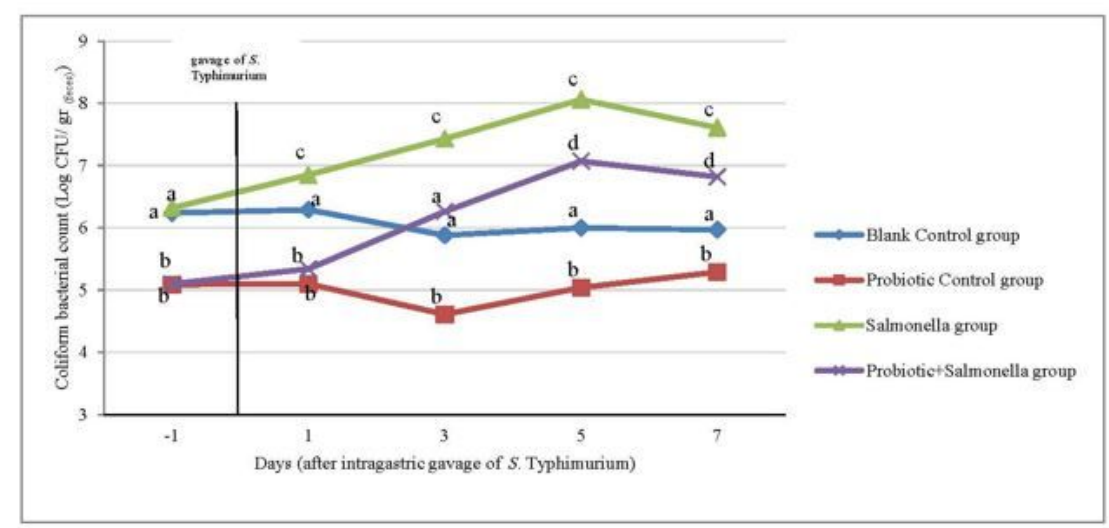

\section{Figure 5}

The logarithm of colifom bacterial count in feces samples of rats with different treatments before and after intragastric gavage of S. Typhimurium. Values are mean of 5 independent replicates. Blank Control group: Receiving water; Probiotic Control group: Receiving water containing $5 \times 107$ spore/ml B. coagulans and $5 \times 107$ spore/ml B. subtilis ; Salmonella group: Receiving water and intragastric gavage of 1×109 CFU S. Typhimurium; Probiotic+Salmonella group: Receiving water containing $5 \times 107$ spore/ml B. coagulans and $5 \times 107$ spore/ml B. subtilis and intragastric gavage of $1 \times 109$ CFU S. Typhimurium. Different letters indicate significant differences between groups in each day $(P<0.05)$.

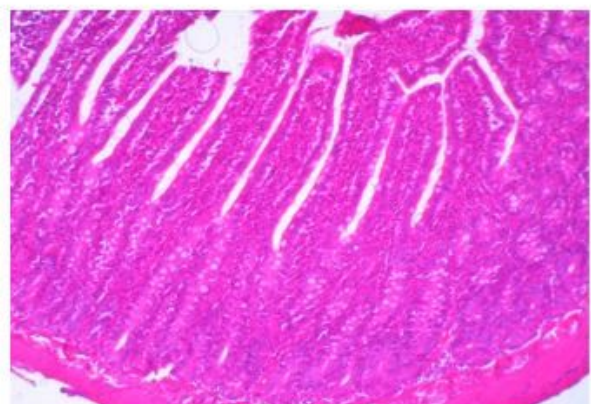

\section{A}

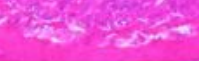
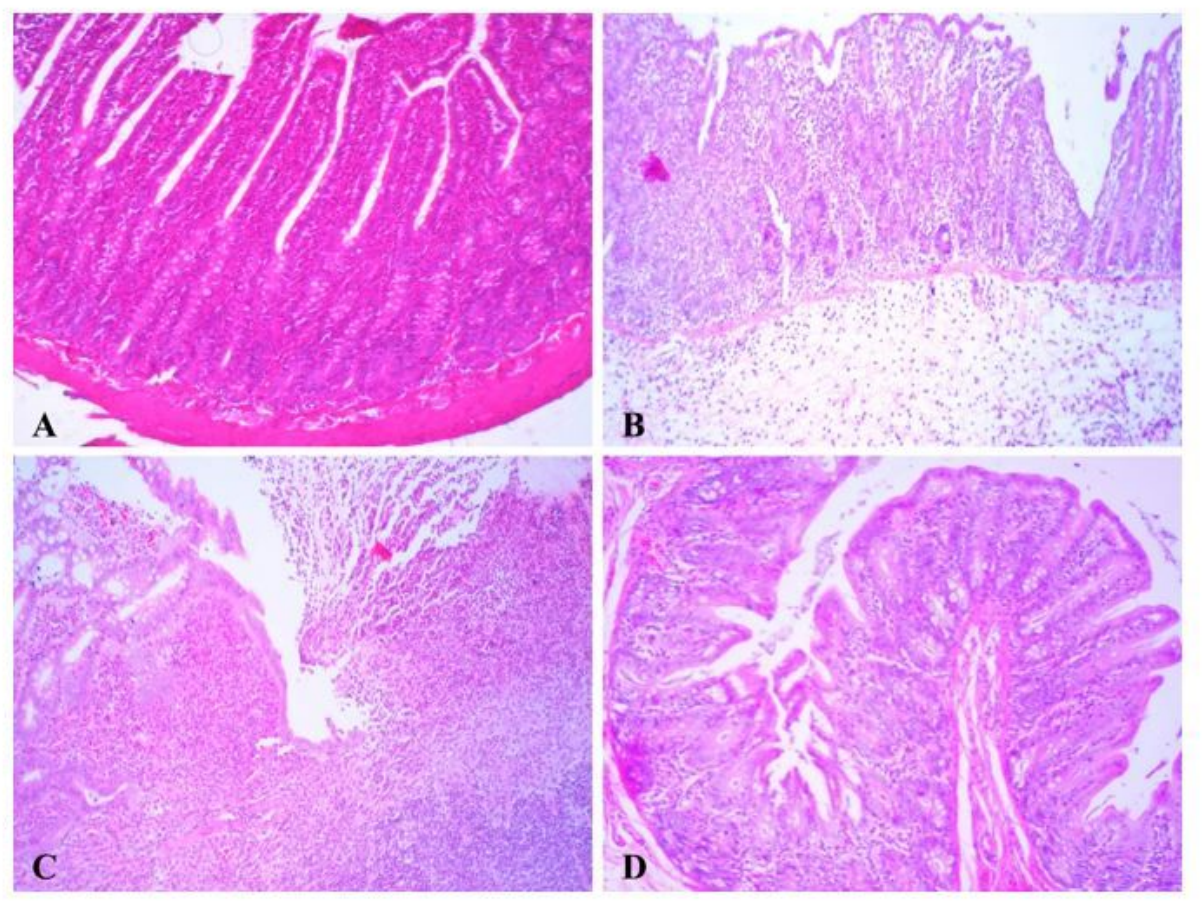

\section{Figure 6}

A photomicrograph of intestinal sections, A: Intact mucosa with normal villi in Blank Control group. B: Severe fusion of intestinal villi, mononuclear cells infiltration and submucosal edema in Salmonella group. C: Severe intestinal necrosis in Salmonella group. D: Mild fusion of intestinal villi in Pro.+Sal. group. H\&E, (× 100). 

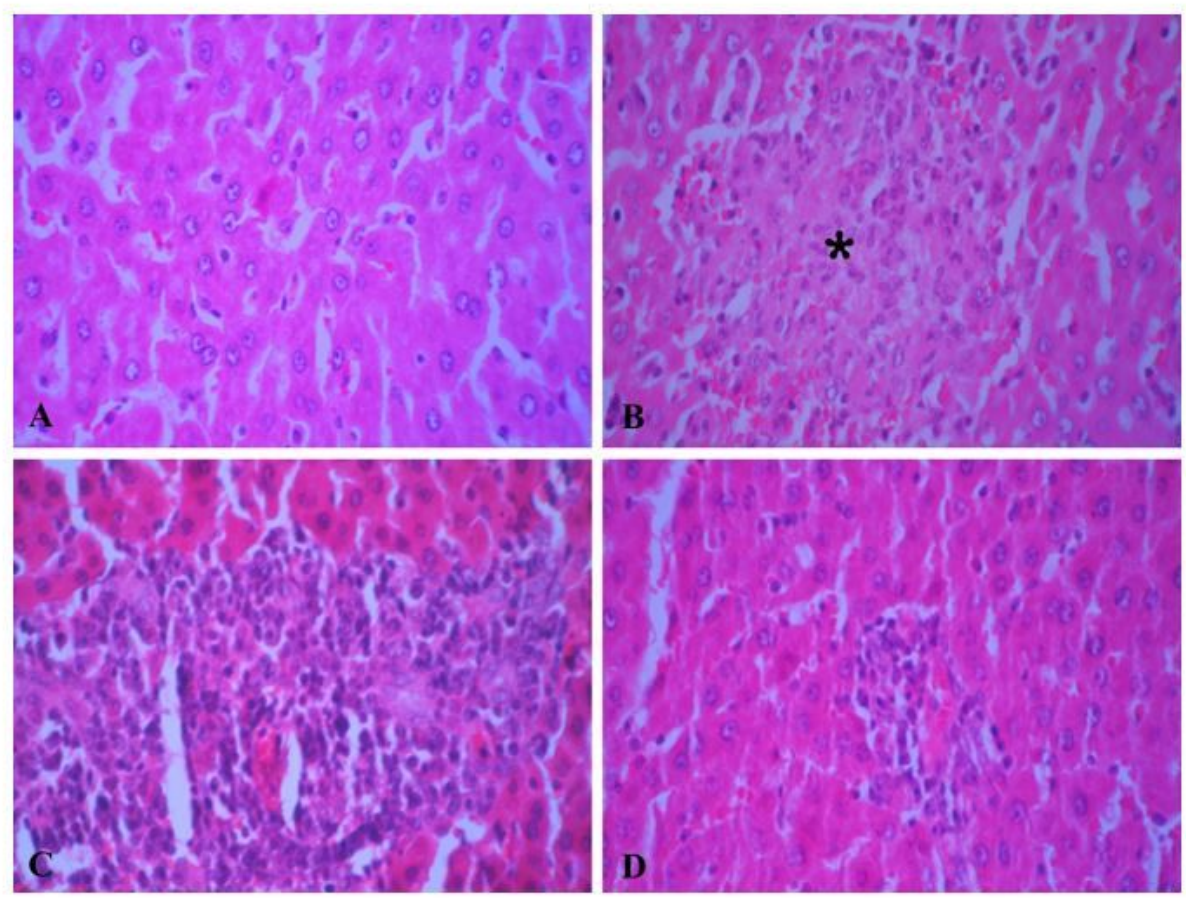

Figure 7

A photomicrograph of liver sections. A: Normal hepatic architecture in Blank Control group. B: Moderate hepatocyte degeneration and necrosis (asterisk) in Salmonella group. C: Severe mononuclear cells infiltration in Salmonella group. D: Mild mononuclear cells infiltration in Pro.+Sal. group. H\&E, (× 1000).

\section{Supplementary Files}

This is a list of supplementary files associated with this preprint. Click to download.

- ARRIVEguidelines.docx 